\title{
Hannah Arendt and the Dark Public Sphere
}

\author{
John LeJeune \\ $\mathrm{PhD}$, Assistant Professor of Political Science, \\ Department of History and Political Science, Georgia Southwestern State University \\ Address: Georgia Southwestern State University Drive, 800, Americus, GA 31709 \\ E-mail: john.lejeune@gsw.edu
}

\begin{abstract}
Hannah Arendt once described "dark times" as characterized by "credibility gaps' and 'invisible government,' by speech that does not disclose what is but sweeps it under the carpet, by exhortations, moral and otherwise, that, under the pretext of upholding old truths, degrade all truth to meaningless triviality." This paper argues that as Western democracies experience conditions that echo Arendt's twentieth century assessment - among these are the death of truth, the decline of civility, and the dearth of authenticity in the public sphere - Arendt's work helps us better understand two sources of this modern crisis. First is the blurring of truth and opinion in contemporary political discourse; second is the blurring of the public and private realms made possible by the coercive intermediation of the social. An acute danger of these circumstances is the lure of demagogues and extreme ideologies when the words and deeds of the public realm - either because they are not believed, or because they have been reduced to mere image-making - increasingly lack meaning, integrity, and spontaneity. A second danger is the erosion of faith in the free press (and with it our common world and basic facts) when the press itself, reacting to its own sense of darkness, undermines its role of truthteller by assuming the role of political actor. In the end I suggest that underlying these several acute issues of democracy lies a more basic tension in the public sphere centered on an Arendtian notion of "freedom of opinion."
\end{abstract}

Keywords: Hannah Arendt, public sphere, free press, lying, fake news, social realm

\section{Election 2016: Crises of Democracy}

The 2016 election of Donald Trump as US President signaled to many a crisis of American democracy. "The blunt fact," wrote Politico's Jeff Greenfield a day after the election, "is that many of the guardrails that were supposed to protect the world's oldest functioning democracy have been shown to be perilously weak, as vulnerable to assault as the Maginot Line was in the face of the German army some 75 years ago" (Greenfield, 2016). The timing of Greenfield's remarks is important. Long before Trump prevaricated in his condemnation of white nationalism after Charlottesville (Godfrey, 2017), or fired the FBI Director responsible for investigating his own campaign (Shear, Apuzzo, 2017), or called members of the American media the "enemy of the people" (Kalb, 2018), Trump's election had by itself signaled that something was irregular, if not disquieting, about the state of American democracy.

At least three concerns stood out. First, from an institutional perspective, the 2016 election cast doubts on democracy's integrity at a time when online information and

(C) John LeJeune, 2018

DOI: 10.17323/1728-192X-2018-4-47-69

(c) Centre for Fundamental Sociology, 2018 
social media consumption were not just increasing, but increasingly entwined. As one scholar summarized, "Those who worry about the implications of the 2016 campaign are left to wonder whether it illustrates the vulnerabilities of democracy in the Internet age, especially when it comes to the integrity of the information voters will access as they choose between candidates" (Persily, 2017: 67). The 2016 campaign saw social media platforms like Facebook and Twitter not only setting the agenda of traditional news media, ${ }^{1}$ but at times displacing them altogether. ${ }^{2}$ Online consumers also faced an unprecedented barrage of sensationalist "fake news" stories and bot-generated Tweets that were intentionally deployed to impact voter behavior and, absent the fact-checking and quality-control mechanisms of traditional media outlets, were hard to consistently distinguish from reality. ${ }^{3}$ All of this ran parallel to an increasingly bitter relationship between candidate Trump and mainstream news organizations, during which the term "fake news" became a unifying rallying cry among Trump supporters, and a linchpin of the mutual accusation between conservative candidates and popular news sources. Critics like Michiko Kakutani (2018) mourned the "death of truth" in current public discourse.

A second problem involved the rise of a new "American populism" catalyzed by Trump's unorthodox campaign. " "Trumpism," as it came to be called, appealed principally to less-educated and lower-income whites and rejected discursive norms of "political correctness" typically associated with respect towards minorities. Juxtaposed with a series of inflammatory remarks towards Mexicans, Muslims, and other groups (Reilly, 2016; Haberman, Oppel Jr., 2016; Beckwith, 2017), the timbre of Trump's rhetoric was often uncomfortably "infused ... with populist imagery based on an assertive, nativist, and arguably xenophobic brand of nationalism" (Ostiguy, Roberts, 2016: 42). ${ }^{5}$ Moreover, the demographics of Trump's political base, combined with his active rejection of political correctness - whether at rally speeches, public appearances, or in seemingly off-thecuff Tweets where caricatured insults like "Little Marco" Rubio and "Crooked Hilary" Clinton were a trademark - led many to associate Trump's rise not only with the "death of civility" in American public discourse (Bybee, 2018), but the reentry into mainstream politics of racist and (for that reason) socially rejected groups. Some weeks after the elec-

1. Wells et al. (2016) discuss the Trump campaign's effective use of this strategy.

2. Silverman's (2016) analysis determined that "in the final three months of the US presidential campaign, the top-performing fake election news stories on Facebook generated more engagement than the top stories from major news outlets such as the New York Times, Washington Post, Huffington Post, NBC News, and others." The study subsequently shows that over these three critical months the "2o top-performing false election stories from hoax sites and hyperpartisan blogs" outperformed the " 20 best-performing election stories from 19 major news websites" in terms of a raw count of shares, reactions, and comments.

3. US intelligence reported that Russia alone hired 1,000 "paid Internet trolls" to steer swing states like Wisconsin, Michigan, and Pennsylvania towards Trump (Papenfuss 2017; see also Shane 2017), and such efforts were hardly unique (Allcott, Gentzkow 2017).

4. The populist trend in the US echoed similar developments in Europe, and both inspired a resurgence of academic interest in the topic. Recent general surveys of populism include Mudde and Kaltwasser (2017) and Müller (2016).

5. Following his election, Trump's words would eventually prompt First Amendment litigation to block a White House executive order restricting entry into the United States from several Muslim-majority countries (see Beckwith, 2017), though a modified version was ultimately upheld by the US Supreme Court. 
tion, Charles Sykes (2016) wrote that “Trump's victory means that the most extreme and irresponsible voices on the right now feel emboldened and empowered. And more worrisome than that, they have an ally in the White House." Well before Election Day, journalists linked Trump's campaign with a "mainstreaming of alt-right ideology" that had "an invigorating effect on an older generation of white nationalists" (Posner, Neiwert, 2016; Neiwert, 2017).

Finally, a third democratic crisis of 2016 involved the so-called "hidden voter." Trump's victory was especially shocking in light of the sizeable discrepancy between preelection polls, which almost universally predicted a Clinton victory, and voter decisions in the ballot booth. In retrospect it appears that public stigmatization (whether real or anticipated) of Trump support led many Trump voters to falsify their preference to pollsters, causing pre-election polls to skew inaccurately towards Clinton. Only two major polls - the USC-Dornsife-LA Times Daybreak and Trafalgar Group of Atlanta polls consistently projected a Trump victory, and their method was revealing: The USC-LA Times poll contacted respondents exclusively online rather than over the phone, and this boosted Trump's numbers considerably. The Trafalgar Group asked respondents who they thought their neighbors were voting for, which also proved crucial for finding the so-called "hidden Trump voter." As one Trafalgar employee put it:

[I]f you want to find out the truth on a hot topic, you can't just ask the question directly. So the neighbor is part of the mechanism to get the real answer. In the 11 battle ground states, and 3 non-battleground, there was a significant drop-off between the ballot test question [which candidate you support] and the neighbors' question [which candidate you believe most of your neighbors support]. The neighbors question result showed a similar result in each state. Hillary dropped [relative to the ballot test question] and Trump comes up across every demographic, every geography. Hillary's drop was between 3 and 11 percent while Trump's increase was between 3 and 7 percent. This pattern existed everywhere from Pennsylvania to Nevada to Utah to Georgia, and it was a constant ... And what we discovered is ... a lot of minorities were shy voters and women were shy voters. (Fossett, Shepard, 2016).

A similar difference was found between live phone call and robocall results, suggesting widespread discomfort among Trump voters in revealing their preferences to other humans.

Thus, ironically, while Trump's election inspired outrage from an array of voices based on things Trump had said over the course of the campaign, others voiced concern over what his supporters had not said out loud - that they supported Trump himself. Perhaps this, too, was a challenge to democracy. A day after the election CNBC's Jake Novak (2016) argued bluntly:

The problem was that too many people felt afraid to answer [the pre-election polls] honestly. For all the focus on how nasty and offensive Trump was, there was a stron-

6. This and the following paragraph draw from the discussion in LeJeune (2017: 1-8). 
ger and steadier stream of nastiness from editorials in major papers, posts on social media, and conversations in office break rooms and classrooms that bashed Trump, sometimes even equating him to Hitler. That took its toll on a lot of Trump supporters ... [I]t's clear millions of Americans have been living for months in fear of saying they intended to vote for him.

It is notable that the United States was hardly alone in this story. For the crises of democracy raised by the 2016 election — crises of truth, civility, and authenticity - were resonating throughout the democratic world. In what Mishra (2017) calls our "age of anger" in a post-9/11 and post-2008-recession world, he argues that "hate-mongering against immigrants and minorities has gone mainstream" (Mishra, 2016) in a range of globally interconnected contexts. In Europe, for example, a myriad of anxieties linked to a perpetual war on terror, a stagnant global economy, and challenges to both private and public interests raised by the chaotic migration of refugees from war-torn areas of North Africa and the Middle East, have propelled parties on the far-right to steady and at times stunning electoral success (Holleran, 2018; Fekete, 2018). No single description captures the range of party platforms generally classified as Far Right (Camus, Lebourg, 2017); many parties reject the label of racist, while others are happy to embrace it (Cummings, 2018). Attached to their electoral success (which includes outright parliamentary majorities in Hungary and Poland) has been an opening of the public sphere to speech once deemed too crass, hateful, or bigoted to command legitimate recognition (Holleran, 2018; Fekete, 2018).

As in the United States, however, this pattern of radical opening has also been accompanied by an attendant sense of closure in the public sphere, the latter manifest in the rise of "hidden voting" as a salient political phenomenon. Most notably, in a June 2016 referendum, British voters shocked pollsters by voting to "leave" the European Union, where the result turned on so-called "shy voters" who hid or falsified their preferences prior to Election Day based on a fear of social ostracism. Much like the Trump campaign, the Leave campaign led by UKIP leader Nigel Farage actively renounced political correctness and often employed crass nationalist messaging, including a particularly dehumanizing "Breaking Point" billboard depicting non-European immigrants as an impersonal mass and British problem. Farage denied the charge of racism, but many Brits who wanted to leave the EU for any number of reasons (not all of which concerned immigration, or did so for inherently racist reasons) feared being associated with this message and ostracized. As reported in The Guardian, one representative voter concealed his preference to 'leave' the EU even from family members, fearing they would misconstrue his economic motives as immigration-based and racist. Another shy 'leave' voter said, "My main concern is immigration because I think the UK is just stretched right now. But I feel that in recent weeks, people have come to associate that opinion with racism, so of course I am not going to speak out about it" (Sanghani, 2016).

This juxtaposition of trends suggests that while extremist, racist, or otherwise hitherto censured forms of speech have exploded into the public sphere, this has also, and ironi- 
cally, catalyzed heightened fears that even moderate but so-called "politically incorrect" speech will bring harm or ostracism. Thus as the democratic space opens to voices which place its outer boundaries under question, much of the space previously within those boundaries seems more inhospitable than ever to precisely those forms of speech it was designed to protect. It is as if, while the outer perimeter of the democratic public space has expanded, and the comfortable center has held steady, a less comfortable but entirely civil space in between has dissolved.

How should one understand this extraordinary confluence of crises in the democratic public sphere, the (1) death of truth, (2) decline of civility, and (3) dearth of authenticity? Are these crises a transient product of strange and extraordinary times (and thus destined to pass), or do they reflect more fundamental pathologies of democracy, and the need for more radical and inventive solutions? If so, what might these creative solutions look like?

To pursue these questions, I turn to the writings of Hannah Arendt, the twentieth century theorist most famous for her 1951 opus The Origins of Totalitarianism.

\section{Hannah Arendt on Crisis and Dark Times}

In the wake of 2016, scholars and journalists alike have often turned to Hannah Arendt (Berkowitz, 2018; Friedman, 2017; Sykes, 2018). ${ }^{7}$ Already popular among academics, ${ }^{8}$ after 2016 Arendt's name became so visible in blogs and editorials that her appropriation itself became a subject of political contention (Romm, 2017). In one particularly scathing piece, Emmett Rensin (2017) argued that "no writer, except perhaps James Baldwin, has had their ethos cannibalized so voraciously by a public that is also so disinterested in the labor of actually reading their work." Rensin called "pretending" to know Hannah Arendt "the favorite activity of the left," done if only to buttress catastrophic visions of Trump's presidency, confirm depictions of his followers as "just fascists", and ignore the concrete grievances that brought him to power.

Serious appropriations of Arendt have drawn useful parallels between Arendt's analysis of the rise of European fascism in the early-to-mid twentieth century, and the conditions surrounding the current resurgence of the Far Right (Isaac, 2016). As this fertile terrain is well tread, this paper pursues a different path by turning the critical lens on democracy itself: If democracy is indeed in crisis, then what endemic problems of democracy itself have recent events revealed? And what might be done to address these issues in pursuit of a healthy and vibrant public sphere?

Such inquiry was a hallmark of Arendt's writing. Crisis for Arendt was not a time to despair, but an opportunity to learn through thinking and critique. In an essay called “The Crisis in Education," for example, Arendt (1993: 174) spoke of "the opportunity, pro-

7. Sales of Arendt's The Origins of Totalitarianism, her classic analysis of European fascism and imperialism, spiked considerably following the November 2016 election: "Commentators have been referencing [Origins] since Donald Trump's election in November," reported The Guardian, "but rarely has this spurred so many people to actually buy a copy" (Williams, 2017; see also Illing, 2017).

8. Walter Laqueur (1998) once cited a Hannah Arendt "cult." 
vided by the very fact of crisis - which tears away facades and obliterates prejudices to explore and inquire into whatever has been laid bare of the essence of the matter," for crisis "becomes a disaster only when we respond to it with preformed judgments, that is, with prejudices." In this respect Arendt's analysis of American politics was distinct. A consistent approach (let us call it the "acute-basic" approach) is implicit in the essays "Reflections on Little Rock," "Lying in Politics," "Civil Disobedience," and "On Violence," all of which respond to immediate American events. Arendt explains her method in a recently published 1957 letter to Robert Maynard Hutchins, who later founded the Center for the Study of Democratic Institutions:

I think it is in the nature of politics that each factual issue of empirical importance discloses its own foundation. Thus, we may be entitled in political research to start from the surface, because every political danger spot is by definition the point where a basic issue breaks the surface ... I therefore am inclined to believe that the best order to follow is the one drawn up by reality itself, that is, to approach basic issues as indicated in the development of acute and politically relevant issues. By this method, it may be possible to attempt the otherwise forbidding task of reexamining basic ideas and traditionally rooted concepts. (Arendt, 2018: 93)

Here Arendt describes a fluid movement from a provisional analysis of the "acute" or immediate issues of the time, to a point of more generalizable revelation about the "basic" or underlying political system itself. Such an approach accomplishes at least two things: First, it keeps the political theorist grounded in political reality and the world of common sense. Second, it employs the fact of crisis to see more clearly the fundamental problems of political life itself.

In the 1971 essay "Lying in Politics," for example, Arendt uses the revelations of the Pentagon Papers, the problem of dishonesty in the American executive branch, and the "famous credibility gap, which has ... suddenly opened up into an abyss" (1972: 3-4), to consider the underlying pathologies of "image-making" as an element of modern democratic politics. In a much different context, Arendt's 1959 essay "Reflections on Little Rock" uses the "acute" issue of school desegregation to explore the more "basic" issue of equality before the law, the particular freedoms attached to the political, social, and private realms, and threats to each of these freedoms which follow when the boundaries between these realms are crossed.

Thinking in Arendt's terms, then, in 2016 the "acute" crises of democracy were manifold. They included the explosion of "fake news" as both a political and rhetorical weapon. They also included the legitimation of offensive or uncivil discourse, on one hand, and the uncomfortable absence from the public realm of more moderate and "hidden" voters. I have characterized these three "acute" issues as the death of truth, the decline of civility, and the dearth of authenticity, respectively. If this is so, then what "basic" issues of modern democracy underlie all three?

9. "Reflections on Little Rock" is found in Arendt (2003), pp. 192-213, while "Lying in Politics," "Civil Disobedience," and "On Violence" are all contained in Arendt (1972), pp. 1-47, 49-102, and 103-198, respectively. 
Tackling this question draws us to a range of Arendt's works. What is initially striking, however, is the underlying element of cynicism each issue projects towards contemporary democratic discourse, as if the public sphere itself has become somehow darker and less edifying. This steers us first to an unlikely source - the collection of biographical essays written throughout Arendt's career called Men in Dark Times (1968). There Arendt addressed the most serious crises of democracy and humanity in the $20^{\text {th }}$ century, refracting often horrific events through the prism of the lives of ten extraordinary people.

Arendt's subjects in Men in Dark Times are eclectic. They range from esteemed writers like Berthold Brecht and Walter Benjamin, to the left-wing revolutionary Rosa Luxemburg, philosopher Karl Jaspers, and even Pope John XXII. And while "it is not difficult to imagine how they might have protested, had they been given a voice in the matter, against being gathered in a common room" (1968: vii) their lives shared a quality that Arendt calls "illumination." Arendt employs this term to invert the Platonic tradition: Where Plato, in the Republic, contrasted the shadows of opinion with the illumination of the good, effectively lifting the perfection of truth above the caprice of human affairs, Arendt seeks to illuminate the very stuff of human affairs. It is as if, where Plato's philosopher prefers to leave the Cave to see metaphysical truth illuminated by the sun, Arendt's heroes stoke the fire within to make the cave itself brighter.

This analogy helps one understand Arendt's concept of "dark times" as not inherently entangled with catastrophe, but representing a general malady of the public sphere. As Arendt (1968: ix) writes in the Preface to Men in Dark Times: "Dark times', in the broader sense I propose here, are as such not identical with the monstrosities of this century which indeed are of a horrible novelty. Dark times, in contrast, are not only not new, they are no rarity in history, although they were perhaps unknown in American history, which otherwise has its fair share, past and present, of crime and disaster." Catastrophes on the scale of the twentieth century - including the inhumanity of twentieth century totalitarianism - are enabled by "dark times," a kind of systematic distortion of reality within the public sphere, whereby the latter's substance is determined:
... not by realities but by the highly efficient talk and double-talk of nearly all of- ficial representatives who, without interruption and in many ingenious variations, explained away unpleasant facts and justified concerns. When we think of dark times and of people living and moving in them, we have to take this camouflage, emanating from and spread by "the establishment" - or "the system," as it was then called — also into account. (Arendt, 1968: viii)

But so too are "dark times" manifest in less extraordinary settings, by the steady and insidious erosion of public faith in the meaning of politics, the integrity of public officials, and the importance of personally engaging in political action at all. As Arendt continues:

If it is the function of the public realm to throw light on the affairs of men by providing a space of appearances in which they can show in deed and word, for better and worse, who they are and what they can do, then darkness has come when this 
light is extinguished by 'credibility gaps' and 'invisible government', by speech that does not disclose what is but sweeps it under the carpet, by exhortations, moral and otherwise, that, under the pretext of upholding old truths, degrade all truth to meaningless triviality. (Arendt, 1968: viii)

Darkness manifests where lying, secrecy, and image-making dominate the public sphere and the political realm, and it shakes the very foundations of democratic politics. Arendt knew this well, for she argues throughout The Origins of Totalitarianism that the death of democratic politics in the $20^{\text {th }}$ century was often preceded by a general sense of political malaise, public meaninglessness, and private loneliness (Gaffney, 2016). This danger remains ever present to modern democracies, which Arendt suggests directly by her conspicuous choice of subjects in the Preface to Men in Dark Times, Martin Heidegger and Jean-Paul Sartre. Neither receives a biographical essay, nor is treated seriously elsewhere in the book. But Arendt suspends their writings, personalities, and biographies over her subsequent essays like a sword of Damocles.

Arendt quotes Heidegger - her most important philosophical mentor alongside Karl Jaspers - several times from the 1927 masterpiece Being and Time, where Heidegger lamented the spiritual emptiness and "mere talk" of the public realm. Arendt observes that Heidegger's initial response to his disgust with public affairs was to turn away from the public and towards philosophy: "There is no escape, according to Heidegger, from the 'incomprehensible triviality' of this common everyday world except by withdrawal from it" (Arendt, 1968: ix). But eventually, Heidegger found something even more abhorrent to fill the spiritual vacuum, as if to compensate for the abhorrent lack of meaning in the public realm and "mere talk" by embracing a brand of politics that professed to freshly imbue the world with an energetic sense of mission, purpose, and reality. He joined the Nazi Party on May 1, 1933 (see Strong, 2012: 263-324, esp. 269-276).

While obviously condemning Heidegger's response to the problem of "dark times," it is important that Arendt accepts fully his diagnosis of what ails the modern public realm: "In our context, the point is that the sarcastic, perverse-sounding statement [of Heidegger's] . . 'The light of the public obscures everything' . . . went to the very heart of the matter and actually was no more than the most succinct summing-up of existing conditions" (Arendt, 1968: ix). Here Heidegger (with Arendt) finds common ground with Jean-Paul Sartre who, at the other end of the political spectrum, stood among the most prominent voices of the radical left: "Nothing of this is new," writes Arendt (1968: viii). "These are the conditions which, thirty years ago, were described by Sartre in $L a$ Nausée (which I think is still his best book) in terms of bad faith and l'espirit de sérieux, a world in which everybody who is publically recognized belongs among the salauds, and everything that is exists in an opaque, meaningless thereness which spreads obfuscation and causes disgust." Arendt's agreement with Sartre in this context is notable, for soon thereafter in "On Violence" she would castigate Sartre at length for his turn to violence as a positive political force - not only for the sake of power, but as a source of existential meaning (see esp. Arendt, 1972: 114-115, 122-123, 185-187). 
The conditions of lying, disgust, and loneliness in relation to the public sphere ring eerily familiar in our times as well. The popularity of "fake news," the pull of radicalism, and the personal alienation from the public realm witnessed throughout contemporary democracies all suggest that beneath these acute problems may lie an underlying condition that Arendt diagnosed a half-century ago as "dark times" in the public sphere. In what follows, I examine these conditions and reconstruct, to the best precision Arendt's writings allow, her own response to these problems as they manifest in the vocation of journalists and the actions of citizens. In both contexts, I suggest that fundamental to Arendt's project is a rigorous maintenance of the distinction between philosophical truth, common sense facts, and political opinion in the democratic public sphere. I also discuss how the illumination Arendt seeks in the public sphere is unsettled by the encroachment of the coercive powers of the social realm upon the private sphere. Finally, I conclude that the basic issue of our times, underlying the three acute problems just discussed, centers on tensions surrounding the Arendtian notion of "freedom of opinion."

\section{Lying and Politics}

The emergence of "fake news" as a salient political phenomenon, whether employed as a tactical device to mislead and sway voters, or a rhetorical trope used to deflect public criticism, raises two related but distinct problems that Arendt tackles in the complimentary essays "Lying in Politics" and "Truth and Politics." The first and more visible of the two concerns the problem of facts. As Arendt argues, both the integrity of factual truth, and the gathering of citizens around common sense facts, constitute an absolute precondition for meaningful political discourse. Arendt tackles this relationship directly in "Truth and Politics" (1993: 238):

Facts and opinions, though they must be kept apart, are not antagonistic to each other; they belong to the same realm. Facts inform opinions, and opinions, inspired by different interests and passions, can differ widely and still be legitimate as long as they respect factual truth. Freedom of opinion is a farce unless factual information is guaranteed and the facts themselves are not in dispute. In other words, factual truth informs political thought just as rational truth informs philosophical speculation.

By "facts" Arendt means nothing more than "brutally elementary data," like "the fact that on the night of August 4, 1914, German troops crossed the frontier of Belgium" (Ibid.: 239). Then with characteristic delicacy, she calls the "opposite" of a fact neither "error" nor "opinion," but the "deliberate falsehood, or lie" (Ibid.: 249). The distinction is critical, because Arendt grounds her political thought on an extraordinary supposition about the relationship between truth and politics: "[H]istorically," she writes, "the conflict between truth and politics arose out of two diametrically opposed ways of life - the life of the philosopher ... and the way of life of the citizen. To the citizens' ever-changing opinions about human affairs, which themselves were in a state of constant flux, the philoso- 
pher opposed the truth about those things which in their very nature were everlasting and from which, therefore, principles could be derived to stabilize human affairs" (Ibid.: 232-233). The Platonic philosopher, bound to the certainties of metaphysical truth, faces a choice when confronted with the messiness of human affairs. Either with disdain he can dissociate from the world, using whatever leisure he has to contemplate the true and eternal; or he may seek to shape the world precisely in the image of philosophical truth.

The latter, often associated with political idealism, Arendt calls "the transformation of ideas into measures," the adoption of "unwavering, 'absolute' standards for political and moral behavior and judgment in the same sense that the 'idea' of a bed in general is the standard for making and judging the fitness of all particular manufactured beds" (1993: 110). This approach to politics, Arendt argues in "What is Authority?," is "the essential characteristic of specifically authoritarian forms of government" (Ibid.: 110-111), because it privileges the authority of philosophical "truth" with its predetermined end over human freedom and spontaneity. It rejects democratic discussion as the play of mere opinions, and subsequently authorizes the wise who bear witness (whether priests, philosophers, or good Marxists) to despotically bring the ignorant and intransigent to heel, through coercion if necessary.

Political freedom is different. Instead of philosophical truth or final answers, "the reality of the public realm," writes Arendt, "relies on the simultaneous presence of innumerable perspectives and aspects in which the common world presents itself and for which no common measurement or denominator can ever be devised." As distinct from the absolute certainty of philosophy, "Under the conditions of a common world, reality is not guaranteed primarily by the 'common nature' of all men who constitute it, but rather by the fact that, differences of position and the resulting variety of perspectives notwithstanding, everybody is always concerned with the same object" (1998: 57-58). The critical element of politics is thus not a determinate agreement upon metaphysical truths, but more simply a common set of agreed-upon facts and objects - what Arendt calls our common world recognized literally by our common senses.

"Only where things can be seen by many in a variety of aspects without changing their identity, so that those who are gathered around them know they see sameness in utter diversity, can worldly reality truly and reliably appear" (Ibid.: 57). This human condition of multiplicity gathered around common objects in the public realm, Arendt calls plurality, ${ }^{10}$ and each person's unique view of the world, attached fundamentally (though not exclusively) to their own unique position, Arendt calls opinion. Politics is subsequently the process through which plural individuals are moved to support public decisions, and often to change their opinions, via the words and deeds of others. The use of stories and arguments to gather support is persuasion; while symbolic or principled deeds that inspire others to follow, Arendt calls action, or the "capacity of beginning something anew" (Ibid.: 9; see also Kane, 2015; Muldoon, 2016).

10. "Plurality is the condition of human action because we are all the same, that is, human, in such a way that nobody is ever the same as anyone else who ever lived, lives, or will live" (Arendt, 1998: 8). 
This depiction of politics can be jarring, for it seems to leave the public sphere without any moral or philosophical banister, without the ballast of authority to tie the public to a common or even decent vision. Arendt's full reckoning with this problem is beyond the scope of this article. ${ }^{11}$ Most fundamentally, however, Arendt ties the very possibility of meaningful judgment and public deliberation to the existence of common sense, manifest in the "brutally elementary data" of "facts." Facts themselves, unlike philosophical or rational truth, do not carry authority because knowledge of the past cannot dictate the future to free humans. But facts are, Arendt insists, the "ground on which we stand" when making collective decisions (1993: 264).

To illustrate this point Arendt, in "Truth and Politics," analogizes political judgment to the judicial process. There are "certain public institutions," she argues, "established and supported by the powers that be, in which, contrary to all political rules, truth and truthfulness have always constituted the highest criterion of speech and endeavor. Among these we find notably the judiciary, which either as a branch of government or as direct administration of justice is carefully protected against social and political power" (Ibid.: 260). As in genuine (rather than feigned) political deliberation, a genuine (rather than show) trial lacks a predetermined outcome. This is why we have a trial; though the trial procedure would collapse entirely were there not basic indisputable facts to ground a judge or jury's deliberations. The same is true with democratic deliberation - absent a set of basic common facts around which people with different opinions and perspectives can gather, meaningful discursive engagement becomes impossible.

An upshot of this is to underscore the pivotal role of the free press to enable meaningful public deliberation. As Arendt writes in "Lying in Politics," "so long as the press is free and not corrupt, it has an enormously important function to fulfill and can rightly be called the fourth branch of government" (1972: 45). Notably, Arendt wrote this in response to the 1971 leak of the Pentagon Papers which exposed a range of deceptions in the US executive branch's conduct of the Vietnam War. When officials requested a halt to their publication, Justice Hugo Black wrote famously in New York Times Co. v. United States (Legal Information Institute, 1971) why the court rejected prior restraint:

In the First Amendment, the Founding Fathers gave the free press the protection it must have to fulfill its essential role in our democracy. The press was to serve the governed, not the governors. The Government's power to censor the press was abolished so that the press would remain forever free to censure the Government. The press was protected so that it could bare the secrets of government and inform the people. Only a free and unrestrained press can effectively expose deception in government. And paramount among the responsibilities of a free press is the duty to prevent any part of the government from deceiving the people and sending them off to distant lands to die of foreign fevers and foreign shot and shell. In my view, far from deserving condemnation for their courageous reporting, the New York Times, the Washington Post, and other newspapers should be commended for serving the

11. Among other things, she sees creative possibilities in the project of revolutionary foundation and the political origins of legitimate constitutions The American Revolution was an especially important model for Arendt in this regard. See Arendt (2006, esp. pp. 132-206), and Arendt (1993), p. 136-141. 
purpose that the Founding Fathers saw so clearly. In revealing the workings of government that led to the Vietnam war, the newspapers nobly did precisely that which the Founders hoped and trusted they would do.

Even with this outcome, Arendt advocates for more robust protection of "unmanipulated factual information" as a constitutional civil right, for "Whether the First Amendment will suffice to protect this most essential political freedom, the right to unmanipulated factual information without which all freedom of opinion becomes a cruel hoax, is another question" (1972: 45).

But employing this essential freedom, in the name of what Arendt calls "freedom of opinion," also comes with a strong caveat. For if the press as the "fourth branch of government" scaffolds and defends the basic facts (the "ground on which we stand" in a discursive democratic public sphere), and is trusted to "look upon politics from the perspective of truth," this in turn also "means to take one's stand outside the political realm." For unless the journalist does so, argues Arendt, he, as truthteller, "forfeits his position - and, with it, the validity of what he has to say - if he tries to interfere directly in human affairs and to speak the language of persuasion or of violence" (Arendt, 1993: 259). It follows that the journalist while she is a journalist must sacrifice her political personality, must above all refrain from the appearance (let alone the reality) of political partisanship, and must actively refrain from trying to persuade the public to reach one political conclusion or another. For "just as the philosopher wins a Pyrrhic victory when his truth becomes the dominant opinion among opinion-holders, the teller of factual truth, when he enters the political realm and identifies himself with some partial interest and power formation, compromises the only quality that could have made his truth appear plausible, namely, his personal truthfulness, guaranteed by impartiality, integrity, independence" (Ibid.: 250).

In less opaque terms, Arendt urges the journalist to report the facts with extreme political circumspection and a minimum of editorializing. The truthteller who discloses facts cannot attempt to dictate what they mean, for this threatens to undermine the integrity of the facts themselves. Above all, the reporter of facts must avoid (except under the most dire circumstances, as under totalitarianism, where telling the truth is itself a kind of action) the appearance of becoming a political actor herself.

It is as if the journalist must herself cease to exist as a political person, and must become a political nobody, if only to enable others to act and deliberate democratically. For as truthtellers, journalists bring nothing new into the world; they only reveal what has been. Just as the "transformation of ideas into measures" was the despotic temptation of philosophy that threatened the very legitimacy of political plurality, so too is the transformation of facts into judgments the tragic temptation of journalism, for it is here that the reporter ceases to stand outside the political realm and becomes a political actor herself (with all the risk and satisfaction this entails). This too threatens to destroy the foundation of democratic politics by undermining public faith in the integrity of the facts themselves and it is for this reason - the necessary sacrifice of political personality 
entailed in the journalist's vocation - that Arendt likens the loneliness of journalism to the solitude of philosophy in a manner that is almost tragic — for each, she says, amounts to "one of the various modes of being alone" (Ibid.: 259).

\section{Image, Action, and Loneliness}

One of the more startling aspects of the democratic crisis of our times concerns not only the prevalence of lying, distortion, and concealment as elements of politics, but the partisan manner in which citizens absorb both factual and fake news narratives. In a summary of recent studies examining the public reception of fake news, The New York Times reports that:

The partisan divide is easy to detect if you know where to look ... But the fakenews phenomenon ... is not limited to one end of the political spectrum. Rather, Americans' deep bias against the political party they oppose is so strong that it acts as a kind of partisan prism for facts, refracting a different reality to Republicans than to Democrats. Partisan refraction has fueled the rise of fake news, according to researchers who study the phenomenon. (Taub, 2017)

Other research suggests that the impetus for the spread of both factual and fake news particularly over social media typically stems from an initial partisan bias that renders a particular story palatable, favorable, and important to the reader, accompanied by an elevated sense of trust between co-partisans when such stories are shared (Rini, 2017).

This partisan trend - particularly when those holding opposing ideological views systematically trust or distrust different news sources (Mitchell et al., 2014) - further erodes public reliance on common facts as part of a common world. As a recent Reuters study involving eight focus group from the US, UK, Spain, and Finland suggests, generally speaking, "The fake news discussion plays out against a backdrop of low trust in news media, politicians, and platforms alike - a generalized skepticism toward most of the actors that dominate the contemporary information environment." Thus "from an audience perspective, fake news is only in part about fabricated news reports narrowly defined, and much more about a wider discontent with the information landscape - including news media and politicians as well as platform companies" (Nielsen, Graves, 2017). In this environment, words and deeds cease to matter in the public realm - either because consumers do not trust them anyway, or because what is said and how it is received by different groups are predictable from the outset.

It is this particular sense of meaninglessness in the public realm - the sense that words and deeds reveal nothing in the public realm and bring nothing new or novel into it - which harbors an especially acute danger for democracy. Not only are facts unreliable, but predictable words and telegraphed deeds in the public sphere lack interest or spontaneity. No longer an arena of genuinely principled or spontaneous action, politics becomes the arena of calculated and cynical "image making." Arendt describes this vividly in "Lying in Politics," that the "recent generation of intellectuals, who grew up in the 
insane atmosphere of rampant advertising ... were taught that half of politics is 'image making' and the other half the art of making people believe in the imagery" (1972: 8). Lying under these circumstances often does not even reach the level of action as Arendt understands it (though it might), but merely serves to project or uphold an image. Knowing this, citizens consume public words and acts with the same skepticism as product ads.

All of this deteriorates the meaning of the public realm. Over time the cynicism surrounding such meaninglessness transmogrifies not only into nausea and disgust, but even a passionate and emotional reaction against a world defined by false words and values. Arendt discusses this phenomenon in the lead up to World War I and the so-called "front generation" in Europe:

Not only Hitler and not only failures thanked God on their knees when mobiliza-
tion swept Europe in 1914. They did not even have to reproach themselves with
having been an easy prey for chauvinist propaganda or lying explanations about
the purely defensive character of the war. The elite went to war with the exultant
hope that everything they knew, the whole culture and texture of life, might go
down in its 'storms of steel' ... Simply to brand as outbursts of nihilism this violent
dissatisfaction with the prewar age and subsequent attempts at restoring it . . is
to overlook how justified disgust can be in a society wholly permeated with the
ideological outlook and moral standards of the bourgeoisie. Yet it is also true that
the 'front generation', in marked contrast to their own chosen spiritual fathers, were
completely absorbed by their desire to see the ruin of this whole world of fake secu-
rity, fake culture, and fake life... Destruction without mitigation, chaos and ruin as
such assumed the dignity of supreme values. (Arendt, 1973:327-328)

Subsequently, Arendt describes what might be called the extreme case under which disgust with the combination of international weakness, spiritual emptiness, and the political ineffectiveness of interwar liberal regimes inspired radical reactions among disaffected elites, who in turn found a discontented following among a mass of people who found themselves socially and culturally excluded from that same bourgeois society. Thus, says Arendt, "The temporary alliance between the elite and the mob rested largely on this genuine delight with which the former watched the latter destroy respectability" (Ibid.: 333). It was precisely these disaffected elites, willing to act by any means necessary, whether through violence, terror, or lies, but all in the name of a unifying movement, who reinvested the disaffected masses with the words and actions of political leaders and the spiritual meaning of politics, if only by their willingness to go to extremes in order to ride the wave of alienation.

Layered onto this problem of alienation - and indeed part and parcel of it - is the mass phenomenon of loneliness and isolation engendered by the blurring of public and private personalities that has dramatically intensified in a world of social media. In the modern democracies in question, both research and anecdotal evidence suggest that "Previously, partisan conflict mostly applied to political issues like taxes or abortion," but now seems "to be operating more like racism or sexism, fueling negative or positive judgments on people themselves, based on nothing more than their party identification" 
(Taub, 2017). Indicative of this trend was White House Press Secretary Sarah Huckabee Sanders and several members of her family being asked to leave a Lexington, Virginia restaurant based on her political affiliation with Donald Trump (Stracqualursi, 2018), following similar treatment dealt to Trump's Homeland Security Secretary Kirstjen Nielsen and adviser Stephen Miller. This was followed by a statement from California Democratic Congresswoman Maxine Waters to, "If you see anybody from that (Trump) Cabinet in a restaurant, in a department store, at a gasoline station, you get out and you create a crowd and you push back on them, and you tell them they're not welcome anymore, anywhere" (Davis, 2018). After Waters's remarks several Democrats, including US Senate Minority Leader Chuck Schumer, publicly renounced such behavior: "I strongly disagree with those who advocate harassing folks if they don't agree with you," said Schumer, "No one should call for the harassment of political opponents. That's not right. That's not American" (Ibid.).

The problem of exclusion in the public realm (and in public accommodations) is, of course, multifaceted and a multitude of factors - including race, gender, language, citizenship status, and class, among others - can systematically affect not only one's access to the public space of democracy, but one's own sense of efficacy when appearing in that space. Here, however, Arendt explains how the breakdown of the separation between the public and private, driven largely by the intermediary role of the social realm, leads to a deterioration of the quality and integrity of public discourse. The problem of social ostracism is one manifestation of this breakdown, for it suggests that no separation can be made between one's public persona - the identity one assumes in public when one voices political opinions that seek to persuade, and when one acts on principles he hopes others will follow - and one's private self, which has other, more basic, needs for security, comfort, and sustenance. But the integrity of either, argues Arendt, requires maintaining their rigid separation in practice: "[O]ur private possessions," she says, "which we use and consume daily, are much more urgently needed than any part of the common world," and "the four walls of one's private property offer the only reliable hiding place from the common public world, not only from everything that goes on in it but also from its very publicity, from being seen and being heard" (1998: 70-71). Shielding this private space from the political, effectively turning the private realm into a holding environment to which one can always retreat, allows one to act with courage and spontaneity in the public sphere.

This separation, however, has broken down largely via the intermediating influence of the social realm through which private citizens, viewed and sanctioned by a faceless mass society, face intense pressure to conform to ostensible public opinion. The effect can be chilling on political speech and action, for "It is decisive that society, on all its levels, excludes the possibility of action, which formerly was excluded from the household. Instead, society expects from each of its members a certain kind of behavior, imposing innumerable and various rules, all of which tend to 'normalize' its members, to make them behave, to exclude spontaneous action or outstanding achievement” (Ibid.: 40). The rule 
of society, though impersonal and diffuse (what Arendt calls a kind of "no-man rule"), is no less coercive because of that fact:

But this nobody, the assumed one interest of society as a whole in economics as well as the assumed one opinion of polite society in the salon, does not cease to rule for having lost its personality. As we know from the most social form of government, that is, from bureaucracy ... the rule by nobody is not necessarily no-rule; it may indeed, under certain circumstances, even turn out to be one of its cruelest and most tyrannical versions. (Ibid.: 40)

The combination of these three factors - (a) the loss of a common world and even a common set of facts; (b) the meaninglessness of political words and deeds when both have been reduced to predictable and ideological image-making; and (c) the chilling effect on political action due to the breakdown of the separation of the public and private via the coercive impact of a rapidly thickening social realm - may help us better understand both the lure of radical and outrageous political platforms in recent years, and the recent phenomenon of "hidden voting" in which citizens express their political preferences secretly but fail to properly appear in the broader public sphere. In the case of the former, radicalism and incivility are not only, or simply, the expression of ideas once deemed too crass or dangerous to enter the public sphere. They also represent the desperate attempt of particular people to find meaning of any kind in a political world in whose reality and integrity they have no faith. Where the world itself seems inauthentic and unreal - where words and deeds in the public realm speak not to reality or common sense, but to ideological pretense and an image of reality carefully crafted by political elites, statisticians, and marketing experts on all sides - there the temptation to ignore the facts, to flaunt the rules of social respectability, and to intentionally upset a carefully crafted reality which itself seems unreal, is large indeed, if only to feel genuine and spontaneous for its own sake.

On the other hand, the obliteration of the sanctity of the private realm via the intermediation of society has enabled the intense blurring of not only our public opinions and private personalities, but the fluid enforcement of public social norms in historically private contexts (including work and, in some cases, the home). This has heightened not only the phenomenon of "hidden voting" in democratic societies, but a commensurate increase of "lying in politics," on a daily basis, by citizens to each other. In this sense the inaccuracy of pre-election polls only partially represents the more profound depth of lying and concealment which takes place among colleagues and even (as we have seen) among friends and family. All of this contributes to a general sense that political words and deeds, whether those of politicians or everyday citizens, ultimately reveal nothing. For while truth is blurred by image, genuine opinion is concealed by citizens who, being thrown willy-nilly into a mass society, fear the punitive retaliation of a network of others who, disagreeing with their opinion, presume to know the truth. 


\section{Conclusion}

We began this essay by citing three acute crises of contemporary democracy - the crises of truth, civility, and authenticity. I have suggested that underlying each of these acute crises is a more basic crisis which Hannah Arendt identified as "dark times." "Dark times" does not correspond to any particular political outcome. It is instead a political condition characterized by "speech that does not disclose what is but sweeps it under the carpet, by exhortations, moral and otherwise, that, under the pretext of upholding old truths, degrade all truth to meaningless triviality" (Arendt, 1968: viii).

The subsequent danger endemic to democracy is at least two-fold. The first is the vacuum of meaning in an image driven public sphere, combined with the tension aroused by mass conformity dictated by the social sphere, which prepares the rise of demagogues. For in dark times a lonely and alienated individual may latch onto tribalism or other divisive movements less for their own sake than as a desperate, even nihilistic search for meaning, action, spontaneity, and freedom. As Arendt wrote in Origins,

Hitler appealed almost exclusively to these sentiments of the front generation. The peculiar selflessness of the mass man appeared here as a yearning for anonymity, for being just a number and functioning only as a cog, for every transformation, in brief, which would wipe out the spurious identifications with specific types or predetermined functions within society ... They were satisfied with blind partisanship in anything that respectable society had banned, regardless of theory or content, and they elevated cruelty to a major virtue because it contradicted society's humanitarian and liberal hypocrisy ... There was no escape from the daily routine of misery, meekness, frustration, and resentment embellished by a fake culture of educated talk ... The point was to do something, heroic or criminal, which was unpredictable and undetermined by anybody else. (Arendt, 1973: 329, 331)

Here the demagogue benefits from the ability to lie, for lying has much in common with action. As Arendt observes with stunning insight: "[T]he deliberate denial of factual truth - the ability to lie - and the capacity to change facts - the ability to act - are interconnected; they owe their existence to the same source: imagination" (1972: 5). Lies and narratives, like action, can bring something new into the world that will inspire others to follow. This can be particularly effective when they irritate the very anxieties, frustrations and disgusts which "dark times" harbor.

The second danger lies in the vulnerability of the free press, arguably the last bastion of defense for the common world of facts upon which any deliberative public sphere must stand. The danger is not only that political actors today question or even undermine the integrity of the facts as reported. It is also that, in response to such provocation, the free press will undermine its own credibility (and with it any hope for a world of common facts) by blurring the line in its own work between reporting facts and casting judgments, and by assuming the role of political actor which is inconsistent with its position as truthteller. One might even suggest that the lying and belligerent politician today lays precisely this trap for the free press by daring its members to position themselves ideologically in 
opposition to political power. For once the journalist assumes the role of a political actor or opposition, it is a short step until the bare facts are crowded out (and undermined) by politically suspect "analysis" or transparent attempts to persuade. Once this happens, the journalist's credible role as truthteller and guardian of democracy quickly collapses.

Yet not all is lost. For a vacuum of meaning and illumination in the public realm also clears the space for novel and extraordinary action - let us call it leadership - which may, in fact, not only cast new light on realities within the public sphere, but open the public sphere to a rejuvenated, enlarged, and fully inclusive civil discourse. If Arendt is correct, then such an act of leadership - whatever it may be - would somehow need to inspire in mass society the humility to acknowledge the gap between truth and opinion in their own thinking. It would also need to inspire in citizens the recognition that it is often those who mistake their own opinions for truth, and who believe most strongly in the truth of their own opinions, who effect the most cruel and irrational tyranny upon others. Not least among them is the tyranny of social opinion itself.

What would such an act be? In other circumstances, whether to protect the free press as the fourth branch of government (Arendt, 1972: 45), or to more robustly ensure citizens' rights to political recognition as civil-disobedient groups (Ibid.: 101), Arendt occasionally summoned the possibility of expanding the scope of First Amendment protections in the United States Constitution, including through Amendments. As it stands the First Amendment explicitly protects the freedoms of speech, press, assembly, and petition. It is telling that as Arendt probes the gaps of these protections, including her identification of "this most essential political freedom, the right to unmanipulated factual information," she sets beside it another novel freedom — "freedom of opinion" (Ibid.: 45). For in examining the three acute issues of our time - the death of truth, the decline of civility, and the dearth of authenticity - it is the latter, a crisis involving the limits and extent of freedom of opinion in the democratic public sphere, that emerges as the basic issue that links all three. For if "freedom of opinion" is hindered by the suppression of truth, and rendered futile by ideological rejection of facts, it is also abused when discourse becomes uncivil, and denied when majority tyranny stifles citizens its effective use.

What, then, would a more robust constitutional protection of "freedom of opinion" look like? And what other contradictions of democracy might that discussion reveal?

\section{References}

Allcott H., Gentzkow M. (2017) Social Media and Fake News in the 2016 Election. Journal of Economic Perspectives, vol. 31, no 2, pp. 211-236.

Arendt H. (1972) Crises of the Republic, New York: Harcourt, Brace \& Jovanovich.

Arendt H. (1993) Between Past and Future: Eight Exercises in Political Thought, New York: Penguin.

Arendt H. (2018) Thinking without a Banister: Essays in Understanding 1953-1975 (ed. J. Kohn), New York: Schocken Books.

Arendt H. (1968) Men in Dark Times, New York: Harcourt, Brace \& Jovanovich. 
Arendt H. (2006) On Revolution, New York: Penguin.

Arendt H. (2003) Responsibility and Judgment, New York: Schocken.

Arendt H. (1998) The Human Condition, Chicago: University of Chicago Press.

Arendt H. (1973) The Origins of Totalitarianism, New York: Harcourt Brace Jovanovich.

Beckwith R. (2017) President Trump's Own Words Keep Hurting His Travel Ban. Time, March 16. Available at: http://time.com/4703614/travel-ban-judges-donald-trumpwords/ (accessed 11 November 2018).

Berkowitz R. (2018) Hypocrisy and Fascism. Amor Mundi: Hannah Arendt Newsletter, August 12. Available at: http://hac.bard.edu/news/post/?item=19909 (accessed 11 November 2018).

Bybee K. (2018) The Rise of Trump and the Death of Civility. Institute for the Study of the Judiciary, Politics, and the Media at Syracuse University, vol. 4.

Camus J. Y., Lebourg N. (2017) Far Right Politics in Europe (trans. J. M. Todd), Cambridge: Belknap Press.

Cummings W. (2018) "Let Them Call You Racist": What Steve Bannon's Remarks Reveal about the Once-Powerful Label. USA Today, March 16. Available at: https://www.usatoday.com/story/news/2018/03/16/bannon-racist-badge-honor/417286002/ (accessed 12 November 2018).

Davis S. (2018) Congressional Leaders Criticize Maxine Waters for Urging Confrontation. NPR, June 25. Available at: https://www.npr.org/2018/06/25/623206039/congressional-leaders-criticize-maxine-waters-for-urging-confrontation (accessed 14 November 2018).

Fekete L. (2018) Europe's Fault Lines: Racism and the Risk of the Right, New York: Verso. Fossett K., Shepard S. (2016) Trade Secrets from the Predictors Who Called a Trump Victory. Politico, November 16. Available at: https://www.politico.com/magazine/ story/2016/11/donald-trump-2016-polls-upset-214461 (accessed 16 November 2018).

Friedman U. (2017) The Real-World Consequences of "Fake News." The Atlantic, December 23. Available at: https://www.theatlantic.com/international/archive/2017/12/ trump-world-fake-news/548888/ (accessed 12 November 2018).

Gaffney J. (2016) Another Origin of Totalitarianism: Arendt on the Loneliness of Liberal Citizens. Journal of the British Society for Phenomenology, vol. 47, no 1, pp. 1-17.

Godfrey E. (2017) The Hidden Meaning of Trump's Charlottesville Remarks. The Atlantic, August 12. Available at: https://www.theatlantic.com/politics/archive/2017/o8/thehidden-meaning-of-trumps-charlottesville-remarks/536688/ (accessed 11 November 2018).

Greenfield J. (2016) Voters Gone Wild: The Story of Election 2016. Politico, November 9. Available at: https://www.politico.com/magazine/story/2016/11/election-2016-voterswild-trump-watergate-crisis-214446 (accessed 11 November 2018).

Haberman M., Oppel Jr. R. (2016) Donald Trump Criticizes Muslim Family of Slain US Soldier, Drawing Ire. The New York Times, July 30. Available at: https://www.nytimes. com/2016/o7/31/us/politics/donald-trump-khizr-khan-wife-ghazala.html (accessed 11 November 2018). 
Holleran M. (2018) The Opportunistic Rise of Europe's Far Right. The New Republic, February 16. Available at: https://newrepublic.com/article/147102/opportunistic-riseeuropes-far-right (accessed 12 November 2018).

Illing S. (2017) A 1951 Book about Totalitarianism is Suddenly Flying off the Shelves. Here's Why. Vox, July 23. Available at: https://www.vox.com/conversations/2017/6/28/15829712/hannah-arendt-donald-trump-brexit-totalitarianism (accessed 12 November 2018).

Isaac J. (2016) How Hannah Arendt's Classic Work on Totalitarianism Illuminates Today's America. Washington Post, December 17. Available at: https://www.washingtonpost.com/news/monkey-cage/wp/2016/12/17/how-hannah-arendts-classicwork/?noredirect=on\&utm_term $=$. ed27864ac778 (accessed 13 November 2018).

Kakutani M. (2018) The Death of Truth: Notes on Falsehood in the Age of Trump, New York: Tim Duggan Books.

Kalb M. (2018) Enemy of the People: Trump's War on the Press, the New McCarthyism, and The Threat to American Democracy, Washington, D.C.: Brookings Institute Press.

Kane L. (2015) Hannah Arendt on the Principles of Political Action. European Journal of Political Theory, vol. 14, no 1, pp. 55-75.

Laqueur W. (1998) The Arendt Cult: Hannah Arendt as Political Commentator. Journal of Contemporary History, vol. 33, no 4, pp. 483-496.

Legal Information Institute (1971) 403 US 713: New York Times Co. v. United States (No. 1873). Available at: https://www.law.cornell.edu/supremecourt/text/403/713 (accessed 14 November 2018).

LeJeune J. (2017) The Pathologies of Democracy: Mill and Winnicott on the Secret Ballot. Questions in Politics, vol. 5, pp. 1-32.

Mishra P. (2017) Age of Anger: A History of the Present, New York: Farrar, Straus \& Giroux.

Mishra P. (2016) Welcome to the Age of Anger. The Guardian, December 8. Available at: https://www.theguardian.com/politics/2016/dec/o8/welcome-age-anger-brexittrump (accessed 12 November 2018).

Mitchell A., Gottfried J., Kiley J., Matsa K. E. (2014) Political Polarization \& Media Habits: From Fox News to Facebook, How Liberals and Conservatives Keep Up with Politics, Washington, D.C.: Pew Research Center.

Mudde C., Kaltwasser C. (2017) Populism: A Very Short Introduction, Oxford: Oxford University Press.

Muldoon J. (2016) Arendtian Principles. Political Studies, vol. 64, no 1, pp. 121-135.

Müller J.W. (2016) What is Populism?, Philadelphia: University of Pennsylvania Press.

Neiwert D. (2017) Alt-America: The Rise of the Radical Right in the Age of Trump, Brooklyn: Verso.

Nielsen R.K., Graves L. (2017) "News You Don't Believe”: Audience Perspectives on Fake News, Oxford: Reuters Institute for the Study of Journalism.

Novak J. (2016) Why Everyone Underestimated the "Stealth Trump Vote." CNBC, November 9. Available at: https://www.cnbc.com/2016/11/o9/stealth-trump-vote-underestimated-commentary.html (accessed 12 November 2018). 
Ostiguy P., Roberts K. (2016) Putting Trump in Comparative Perspective: Populism and the Politicization of the Sociocultural Low. Brown Journal of World Affairs, vol. 23, no 1 , pp. $25-50$.

Papenfuss M. (2017) 1,00o Paid Russian Trolls Spread Fake News On Hilary Clinton, Senate Intelligence Head Told. Huffington Post, March 31. Available at: https://www. huffingtonpost.com/entry/russian-trolls-fake-news_us_58dde6bae4bo8194e3b8d5c4 (accessed 11 November 2018).

Persily N. (2017) Can Democracy Survive the Internet?. Journal of Democracy, vol. 28, no 2, pp. 63-76.

Posner S., Neiwert D. (2016) How Trump Took Hate Groups Mainstream. MotherJones, October 14. Available at: https://www.motherjones.com/politics/2016/10/donaldtrump-hate-groups-neo-nazi-white-supremacist-racism/ (accessed 12 November 2018).

Reilly K. (2016) Here Are All the Times Donald Trump Insulted Mexico. Time, August 31. Available at: http://time.com/4473972/donald-trump-mexico-meeting-insult/ (accessed 11 November 2018).

Rensin E. (2017) You Don't Know Hannah Arendt. The Outline, January 31. Available at: https://theoutline.com/post/98o/misinterpreting-hannah-arendt?zd=1\&zi=oksjtiws (accessed 12 November 2018).

Rini R. (2017) Fake News and Partisan Epistemology. Kennedy Institute of Ethics Journal, vol. 27, no 2. Available at: https://kiej.georgetown.edu/fake-news-partisan-epistemology/ (accessed 14 November 2018).

Romm J. (2017) How Hannah Arendt is Being Used and Misused in the Age of Trump. The Forward, February 2. Available at: https://forward.com/culture/362036/how-hannah-arendt-is-being-used-and-misused-in-the-age-of-trump/ (accessed 12 November 2018).

Sanghani R. (2016) Welcome to Brexit Britain: A Nation of Secret Leave Voters Too Afraid to Own Up. The Telegraph, June 24. Available at: https://www.telegraph.co.uk/women/ politics/welcome-to-brexit-britain---a-nation-of-secret-leave-voters-too/ (accessed 12 November 2018).

Shane S. (2017) The Fake Americans Russia Created to Influence the Election. The New York Times, September 7. Available at: https://www.nytimes.com/2017/o9/o7/us/politics/russia-facebook-twitter-election.html (accessed 11 November 2018).

Shear M., Apuzzo M. (2017) F.B.I. Director James Comey is Fired by Trump. The New York Times, May 9. Available at: https://www.nytimes.com/2017/05/o9/us/politics/ james-comey-fired-fbi.html (accessed 11 November 2018).

Silverman C. (2016) This Analysis Shows How Viral Fake Election News Stories Outperformed Real News on Facebook. BuzzFeed News, November 16. Available at: https:// www.buzzfeednews.com/article/craigsilverman/viral-fake-election-news-outperformed-real-news-on-facebook (accessed 11 November 2018). 
Stracqualursi V. (2018) Sarah Sanders Says She Was Kicked Out of Restaurant because She Works for Trump. CNN, June 24. Available at: https://www.cnn.com/2018/o6/23/politics/sarah-sanders-restaurant-kicked-out/index.html (accessed 14 November 2018).

Strong T. (2012) Politics Without Vision: Thinking Without a Banister in the Twentieth Century, Chicago: University of Chicago Press.

Sykes C. (2016) Donald Trump and the Rise of Alt-Reality Media. Politico, November 25. Available at: https://www.politico.com/magazine/story/2016/11/donald-trumpconservative-media-charlie-sykes-214483 (accessed 11 November 2018).

Sykes C. (2018) When Everything is Possible and Nothing is True. The Weekly Standard, May 9. Available at: https://www.weeklystandard.com/charles-j-sykes/when-everything-is-possible-and-nothing-is-true (accessed 12 November 2018).

Taub A. (2017) The Real Story About Fake News is Partisanship. The New York Times, January 11. Available at: https://www.nytimes.com/2017/01/11/upshot/the-real-storyabout-fake-news-is-partisanship.html (accessed 14 November 2018).

Wells C et al. (2016) How Trump Drove Coverage of the Nomination: Hybrid Media Campaigning. Political Communication, vol. 33, no 4, pp. 669-676.

Williams Z. (2017) Totalitarianism in the Age of Trump: Lessons from Hannah Arendt. The Guardian, February 1. Available at: https://www.theguardian.com/us-news/2017/ feb/o1/totalitarianism-in-age-donald-trump-lessons-from-hannah-arendt-protests (accessed 12 November 2018).

\title{
Ханна Арендт и «темная» публичная сфера
}

\author{
Джон Лежён \\ $\mathrm{PhD}$, доцент департамента истории и политических наук, Юго-западный университет штата Джорджия \\ Адрес: Georgia Southwestern State University Drive, 800, Americus, GA 31709 \\ E-mail: john.lejeune@gsw.edu
}

\begin{abstract}
Ханна Арендт однажды так охарактеризовала «темные времена»: «кризис доверия» и «закулисное правительство» - это выражения, не раскрывающие, а затемняющие суть происходящего, это моральные призывы, которые под предлогом защиты любую истину низводят до бессмысленного трюизма. Опыт западных демократий созвучен оценкам Арендт в отношении XX столетия, в частности, она указывала на смерть истины, упадок гражданственности, утрату аутентичности в публичной сфере, а следовательно, ее работы позволяют лучше понять два источника современного кризиса. Первый - стирание границ между истиной и мнением в современном политическом дискурсе. Второй - размывание границ между публичной и частной сферами, случившееся из-за насильственного вмешательства социального. Критическая опасность этих обстоятельств состоит в том, что они приводят к расцвету популистских и радикальных идеологий, в которых слова и поступки в публичной сфере — либо в силу того, что в них не верят, либо в силу того, что они сводятся к созданию имиджа - лишены смысла, целостности и спонтанности. Вторая опасность заключается в разрушении веры в свободную прессу (и вместе с этим в наличие общего для всех нас мира и достоверные факты), когда средства массовой
\end{abstract}


информации, опираясь на собственное понимание «тьмы», нивелируют свою роль в качестве распространителя истины и берут на себя роль политического субъекта. В статье высказывается предположение, что в основе указанных опасностей для демократии лежит более фундаментальная напряженность в публичной сфере, связанная с понятием «свободы мнения» Ханны Арендт.

Ключевые слова: Ханна Арендт, публичная сфера, свобода прессы, ложь, фейковые новости, социальная сфера 